Volume : 6

Nomor : 4

Bulan : November

Tahun : 2020

\title{
Pelestarian Taman Nasional Bogani Nani Wartabone Berbasis Lembaga Sosial Agama
}

\author{
Rudy Harold \\ Ridwan Ibrahim \\ Universitas Negeri Gorontalo \\ Pos-el: ridwan@ung.ac.id,rudy_harold@ung.ac.id
}

DOI: 10.32884/ideas.v6i4.296

\begin{abstract}
Abstrak
Tujuan penelitian ini adalah untuk menganalisis tentang peran Gereja Masehi Injili Bolaang Mongondow (GMIBM) dalam upaya melestarikan dan mencegah sumber daya alam Taman Nasional Bogani Nani Wartabone (TNBNW) di wilayah Kecamatan Dumoga Barat Kabupaten Bolaang Mongondow. Metode yang digunakan adalah metode kualitatif dengan analisis dan pendekatan desktiptif. Hasil penelitian menunjukkan bahwa GMIBM berdasarkan ajaran agama, secara fungsional dapat mengajak umatnya untuk memelihara dan melestarikan TNBNW. Namun, secara struktural, GMIBM tidak dapat memengaruhi kebijakan pemerintah untuk memberikan kesempatan kepada umatnya mengolah sebagian kecil TNBNW demi kesejahteraan umat GMIBM. Tingkat ketergantungan umat GMIBM terhadap TNBNW sangat tinggi. Selain karena lokasi pemukiman mereka berbatasan langsung dengan TNBNW, lahan pertanian dan perkebunan yang ada sekarang juga sudah tidak dapat memenuhi kebutuhan ekonomi masyarakat di Kecamatan Dumoga Barat. Sehingganya, sebagian masyarakat telah memanfaatkan wilayah TNBNW sebagai lahan pertanian dan perkebunan untuk kelangsungan ekonomi keluarga.
\end{abstract}

\section{Kata Kunci}

Pelestarian, taman nasional, lembaga sosial agama

\begin{abstract}
The purpose of this study was to analyze the role of Gereja Masehi Injili Bolaang Mongondow (GMIBM) in an effort to conserve and prevent the natural resources of the Taman Nasional Bogani Nani Wartabone (TNBNW) in the West Dumoga District, Bolaang Mongondow Regency. The method used is a qualitative method with descriptive analysis and approach. The results showed that GMIBM based on religious teachings, can functionally invite its people to develop and preserve TNBNW. However, structurally, GMIBM cannot influence government policy to provide opportunities for its people to process a small portion of TNBNW for the welfare of the GMIBM community. The level of dependence of the GMIBM community on TNBNW is very high. Apart from the location of their settlements directly adjacent to TNBNW, existing agricultural and plantation lands are also unable to meet the economic needs of the people in West Dumoga District. So that, some communities have used the TNBNW area as agricultural and plantation land for the survival of the family economy.
\end{abstract}

Keywords

Preservation, national parks, religious social institutions

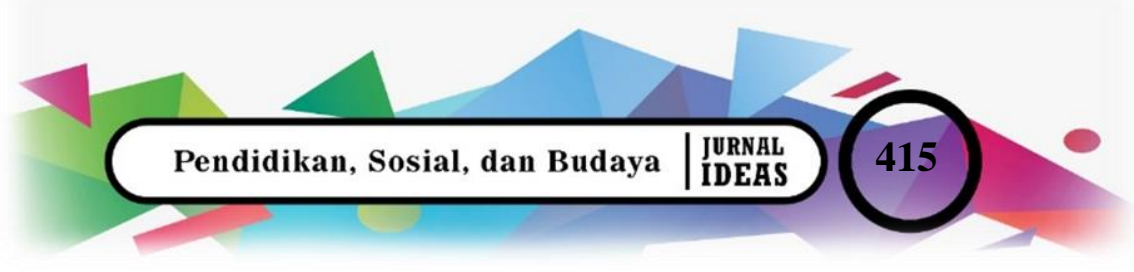




\section{Pendahuluan}

Hutan merupakan paru-paru bumi tempat berbagai satwa hidup, pohon-pohon, hasil tambang dan berbagai sumber daya lainnya yang bisa kita dapatkan yang tak ternilai harganya bagi manusia. Hutan juga merupakan sumber daya alam yang memberikan manfaat besar bagi kesejahteraan manusia, baik manfaat tangible yang dirasakan secara langsung, maupun intangible yang dirasakan secara tidak langsung. Manfaat langsung seperti penyediaan kayu, satwa, dan hasil tambang, sedangkan manfaat tidak langsung seperti manfaat rekreasi, perlindungan dan pengaturan tata air, pencegahan erosi. Daya dukung hutan terhadap segala aspek kehidupan manusia, satwa, dan tumbuhan sangat ditentukan pada tinggi rendahnya kesadaran manusia akan arti penting hutan di dalam pemanfaatan dan pengelolaan hutan. Hutan menjadi media hubungan timbal balik antara manusia dan makhluk hidup lainnya dengan faktor-faktor alam yang terdiri dari proses ekologi dan merupakan suatu kesatuan siklus yang dapat mendukung kehidupan (Reksohadiprojo, 2000).

Bagi masyarakat di sekitar hutan, kekayaan alam yang terkandung dalam hutan adalah sumber kehidupan dan ekonomi. Terkadang, pemanfaatan sumber daya alam oleh masyarakat di sekitar hutan ini berdampak pada kerusakan hutan dan menjadi ancaman bagi kelestarian hayati dan berbagai ragam jenis hewan yang sudah terancam punah. Taman Nasional Bogani Nani Wartabone (TNBNW) adalah salah satu kawasan vegetasi hutan tropis yang hingga saat ini masih terancam kelestariannya akibat dari aktivitas manusia yang lebih mengutamakan manfaat ekonomis dari suatu kawasan hutan.

TNBNW terletak di dua provinsi, yakni Sulawesi Utara dan Gorontalo. TNBNW merupakan kawasan konservasi hutan terbesar di Sulawesi dengan luas wilayah 282.008 hektar, terbagi atas zona inti 175.120 hektar, zona hutan 74.701 hektar, zona pemanfaatan 23.223 hektar, dan zona rehabiltasi 8.962 hektar. Kawasan konservasi ini memiliki keanekaragaman hayati yang tinggi dan menjadi habitat bagi beragam jenis endemik Sulawesi. Sangat bernilainya kawasan konservasi TNBNW ini juga karena ada kurang lebih 400.000 jiwa penduduk tersebar di 125 desa di Sulawesi Utara yang sumber airnya bergantung pada kelestarian hutan di TNBNW.

Namun, sangat disayangkan bahwa hingga saat ini kekayaan alam di kawasan konservasi darat tersebut mengalami kerusakan dan terancam punah. Hal itu disebabkan oleh illegal logging, perdagangan satwa yang dilindungi, dan perambahan hutan untuk keperluan pertambangan dan perkebunan. Informasi yang diperoleh dari media online "Mongabay" 
Volume : 6
Nomor : 4
Bulan : November
Tahun : 2020

mengungkapkan bahwa kasus tindak pidana yang terjadi di TNBNW berfluktuasi tiap tahunnnya. Untuk mengurangi tindak pengrusakan di TNBNW, dibutuhkan adanya kepedulian dan keterlibatan dari masyarakat, khususnya yang bermukim di sekitar daerah penyangga TNBNW. Itulah sebabnya keterlibatan berbagai lembaga sosial, termasuk di dalamnya lembaga-lembaga agama yang ada di sekitar daerah penyangga TNBNW sangat diharapkan. Salah satu lembaga agama itu adalah Gereja Masehi Injili Bolaang Mongondow.

Mengingat pentingnya arti hutan bagi masyarakat, maka peranan dan fungsi hutan tersebut perlu dikaji lebih lanjut. Pemanfaatan sumber daya alam hutan apabila dilakukan sesuai dengan fungsi yang terkandung di dalamnya, seperti adanya fungsi lindung, fungsi suaka, fungsi produksi, fungsi wisata dengan dukungan kemampuan pengembangan sumber daya manusia, ilmu pengetahuan dan teknologi, akan sesuai dengan hasil yang ingin dicapai.

\section{Metode}

Penelitian ini dilaksanakan di kawasan Taman Nasional Bogani Nani Wartabone (TNBNW) dengan titik lokasi berada di Kecamatan Dumoga Barat Kabupaten Bolaang Mongondow, Provinsi Sulawesi Utara. Metode yang digunakan adalah metode kualitatif dengan analisis data secara deskriptif kualitatif. Sumber data berasal dari data primer dan data sekunder. Teknik pengumpulan data secara kualitatif diperoleh melalui observasi dan wawancara, sedangkan pengumpulan data secara kuantitatif diperoleh melalui data dokumentasi. Metode kualitatif digunakan untuk menganalisis tentang perubahan paradigma dan memahami realitas yang terjadi pada masyarakat. Sementara itu, analisis data secara deskriptif digunakan untuk menguraikan segala permasalahan yang ada, juga untuk merekonstruksi kondisi lokasi penelitian.

\section{Hasil dan Pembahasan}

\section{Hasil}

\section{Kawasan Konservasi TNBNW}

Kawasan konservasi ini dihuni oleh beberapa satwa endemik yang dilindungi, di antaranya adalah burung maleo, anoa, dan babi rusa. Selain itu, kawasan ini juga menjadi ekosistem bagi 125 jenis burung, 24 jenis amfibi dan reptil, serta 289 jenis pohon. TNBNW juga menjadi tempat bertumbuhnya beberapa flora endemik seperti cempaka, palem matayangan dan nantu. Untuk melestarikan kekayaan biodiversity yang terkandung di TNBNW, pemerintah membentuk Balai Taman Nasional Bogani Nani Wartabone sebagai 
lembaga yang diberikan wewenang untuk mengorganisasi upaya pelestarian kekayaan alam di TNBNW yang berada di bawah Dirjen Konservasi SDA dan Ekosistem Kementerian Lingkungan Hidup dan Kehutanan RI. Sekitar tahun 2016, Balai Taman Nasional Bogani Nani Wartabone menerapkan sistem RBM (Resort Based Management) dalam menata pelaksanaan fungsi dari balai konservasi.

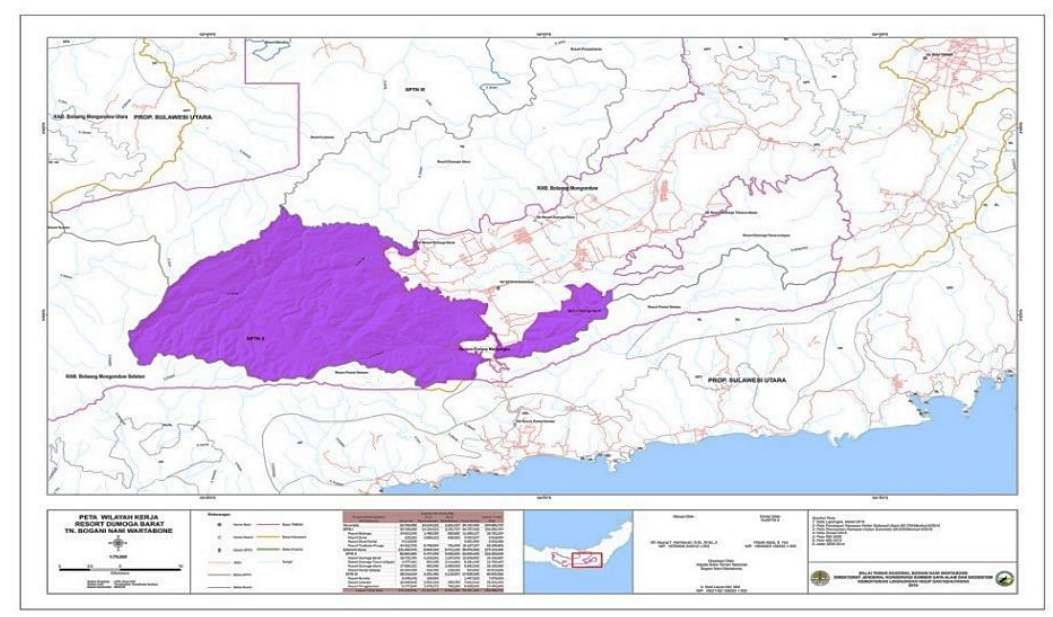

Sumber: Balai TNBNW, Dirjen Konservasi SDA

dan Ekosistem Kementrian Lingkungan Hidup dan Kehutanan

Wilayah yang berwarna ungu menunjukkan area kawasan TNBNW yang berada di bawah pengawasan Resort Dumoga Barat yang luasnya kurang lebih 34.336.687 ha dengan penataan zonasi sebagai berikut.

1. Zona inti : 18.725 .784 ha

2. Zona pemanfaatan: 4.316 .001 ha

3. Zona Rehabilitas : 1.257 .949 ha

4. Zona Rimba : $\quad 10.036 .042$ ha

\section{GMIBM di Wilayah Dumoga Barat}

Gereja Masehi Injili di Bolaang Mongondow (GMIBM) di Dumoga Barat tidak dapat dipisahkan dari sejarah penyebaran agama Kristen (pekabaran injil) di Kabupaten Bolaang Mongondow. Dari catatan sejarah dan data statistik GMIBM, diketahui bahwa jemaat GMIBM sebagian besar berasal dari suku Bolaang Mangondow dan suku Minahasa yang berimigrasi pada tahun 1948 ke daerah Bolaang Mongondow. Pada tahun 1950-an dataran Dumoga kedatangan penduduk Minahasa yang menganut agama Kristen.

Hingga saat ini, di wilayah administrasi Kecamatan Dumoga Barat, terdapat delapan nama jemaat GMIBM dengan jumlah jiwa kurang lebih 1.129 orang. Kedelapan jemaat tersebut di satukan dalam wilayah Doloduo. 
Volume : 6

Nomor : 4

Bulan : November

Tahun : 2020

Tabel 1

Daftar Jemaat GMIBM di Wilayah Duloduo

\begin{tabular}{|c|l|l|c|}
\hline No. & \multicolumn{1}{|c|}{ Nama Jemaat } & \multicolumn{1}{|c|}{ Lokasi } & $\begin{array}{c}\text { Jumlah } \\
\text { Jemaat }\end{array}$ \\
\hline 1 & GMIBM Jemaat Zaitun & Desa Matayangan & 36 \\
\hline 2 & GMIBM Jemaat Pniel & Desa Uuwan & 30 \\
\hline 3 & GMIBM Jemaat Betsaida & Desa Uuwan & 350 \\
\hline 4 & GMIBM Jemaat Imanuel & Desa Ikhwan & 95 \\
\hline 5 & GMIBM Jemaat Efrata & Wangga Baru & 30 \\
\hline 6 & GMIBM Jemaat Eben-Haezer & Desa Doloduo I & 270 \\
\hline 7 & GMIBM Jemaat Sion & Desa Mekaruo & 280 \\
\hline 8 & GMIBM Jemaat Patmos & Desa Toraut Utara & 38 \\
\hline \multicolumn{3}{|c|}{ Total } & 1.129 \\
\hline
\end{tabular}

Sumber: Fauziah, (2019: 62)

Ditinjau dari sumber mata pencaharian, sebagian besar jemaat GMIBM di wilayah ini menekuni pekerjaan utama sebagai petani. Selebihnya bekerja sebagai pegawai (pemerintah/swasta) dan wirausaha. Karena desakan semakin meningkatnya biaya kebutuhan hidup, beberapa keluarga jemaat menanggulangi masalah ini dengan cara mencari sumber penghasilan tambahan. Dari keterangan informan penelitian, beberapa di antara keluarga tersebut bekerja sebagai penambang di beberapa lokasi penambangan tanpa izin (PETI) di wilayah konservasi TNBNW.

\section{Pemanfaatan TNBNW oleh GMIBM}

Bila mengacu pada peraturan menyangkut Tata Kelola Taman Nasional, yakni UndangUndang No. 5 Tahun 1990 dan UU No. 41 Tahun 1999, segala bentuk pemanfaatan sumber daya alam di wilayah taman nasional terkecuali untuk keperluan pendidikan, penelitian, budi daya, dan pariwisata dianggap sebagai tindakan pemanfaatan yang ilegal. Kebijakan ini jelas tidak membuka ruang bagi masyarakat sekitar atau penduduk di desa-desa penyanggah taman nasional untuk mengambil manfaat dari sumber daya alam yang ada di wilayah taman nasional.

Namun, kenyataan yang dapat ditemukan di kawasan TNBNW wilayah kerja Resort Dumoga Barat, terjadi beberapa tindakan pemanfaatan masyarakat sekitar TNBNW yang dikategorikan ilegal oleh pihak pemerintah. Berdasarkan informasi dari pihak pengelola Resort Dumoga Barat, beberapa bentuk pemanfaatan yang melanggar aturan tersebut dapat dilihat pada tabel di bawah ini.

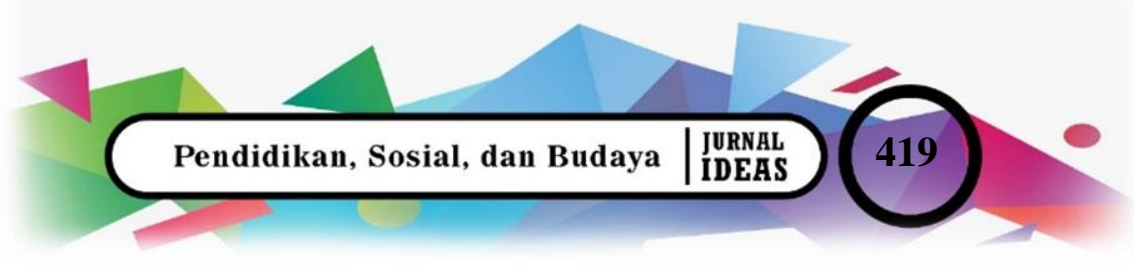


DE-ISSH: 2656-940X

URL: jurnal.ideaspublishing.co.id
Volume : 6

Nomor : 4

Bulan : November

Tahun : 2020

Tabel 2

Pemanfaatan TNBNW oleh Masyarakat

\begin{tabular}{|c|c|c|c|}
\hline No. & $\begin{array}{c}\text { Tanggal } \\
\text { Penemuan }\end{array}$ & Uraian Pemanfaatan & Lokasi \\
\hline \multicolumn{4}{|c|}{ Januari 2020} \\
\hline 1 & 22 & Pembalakan & Binaunga, Desa Toraut Induk \\
\hline 2 & 24 & Pembalakan & Owasi, Toraut Tengah \\
\hline 3 & 25 & Lahan Perkebunan & Tumpasan \\
\hline 4 & 26 & Pembalakan & Sampaka, Toraut Tengah \\
\hline 5 & 28 & Pembalakan & Matayangan \\
\hline 6 & 29 & Pembalakan & Matayangan \\
\hline \multicolumn{4}{|c|}{ Februari 2020} \\
\hline 7 & 13 & Pembalakan & Owasi, Toraut Tengah \\
\hline 8 & 15 & Pembalakan & Baturapa \\
\hline 9 & 18 & Pembalakan & Umbungan, Desa Uuwan \\
\hline 10 & 19 & $\begin{array}{c}\text { Lahan Perkebunan } \\
\text { Pembalakan }\end{array}$ & $\begin{array}{l}\text { Baturapa } \\
\text { Baturapa }\end{array}$ \\
\hline 11 & 17 & Lahan Perkebunan & Binuanga \\
\hline 12 & 21 & Lahan Perkebunan & Luwoot \\
\hline 13 & 22 & Pembalakan & Matayangan \\
\hline \multicolumn{4}{|c|}{ Maret 2020} \\
\hline 14 & 4 & Lahan Perkebunan & Umbungan, Desa Uuwan \\
\hline 15 & 6 & Pertambangan & Hulu Tonom \\
\hline 16 & 7 & Pertambangan & Tayab \\
\hline 17 & 10 & Lahan Perkebunan & Tumokang \\
\hline \multicolumn{4}{|c|}{ April 2020} \\
\hline 18 & 13 & Lahan Perkebunan & Hulu Tonom \\
\hline 19 & 16 & Pembalakan & Binuanga, Toraut \\
\hline 20 & 16 & Pembalakan & Binuanga, Toraut \\
\hline \multicolumn{4}{|c|}{ Mei 2020} \\
\hline 21 & 07 & Lahan Perkebunan & Tumokang \\
\hline 22 & 12 & Pembalakan & Batu Rapa \\
\hline 23 & 13 & Pembalakan & Owasi \\
\hline 24 & 14 & Pembalakan & Sampak, Luwoot \\
\hline
\end{tabular}

Sumber: Laporan Kegiatan Patroli Smart RBM Resort Dumoga Barat Bulan Januari-Mei 2020

Penggunaan TNBNW yang tidak sesuai aturan tersebut sangat terkait erat dengan kondisi ekonomi masyarakat di sekitar kawasan TNBNW, pertambahan jumlah penduduk, desakan kebutuhan keluarga yang meningkat, rendahnya tingkat pendidikan. Selain itu, sangat terkait pula dengan ketergantungan pada ekonomi pertanian, pertumbuhan ekonomi daerah yang lambat, dan sejumlah faktor lainnya turut memengaruhi masih seringnya masyarakat sekitar taman nasional menggunakan kawasan konservasi tersebut secara ilegal.

Pemanfaatan lahan perkebunan oleh warga GMIBM yang di kawasan TNBNW dilatarbelakangi oleh desakan kebutuhan hidup (ekonomi) dan sudah semakin berkurangnya 
Volume : 6

Nomor : 4

Bulan : November

Tahun : 2020

lahan perkebunan yang berada di luar TNBNW. Demikian pula dengan warga GMIBM yang bermata pencaharian sebagai penambang emas tanpa izin, terpaksa melakukan penambangan secara ilegal di kawan TNBNW karena keterdesakan ekonomi yang mereka alami.

\section{Upaya GMIBM Dalam Melestarikan Kawasan TNBNW}

Pada aras sinodal, tanggung jawab GMIBM terhadap perlindungan alam dari kerusakan akibat ulah manusia sangat jelas teraktakan dalam visi GMIBM periode 2016-2021, yakni terwujudnya GMIBM yang solid, inklusif, mandiri dan memelihara keutuhan ciptaan. Untuk mewujudkan visi tersebut, GMIBM menyusun Pokok-Pokok Tugas Panggilan GMIBM yang menjadi pedoman dalam penyusunan program Badan Pekerja Sinode GMIBM tiap tahunnya. Visi tersebut di atas adalah bagian tak terpisahkan dari Pokok-Pokok Tugas Panggilan GMIBM periode pelayanan tahun 2016-2021.

Mengacu pada PTP-GMIBM tersebut, gereja-gereja yang tergabung dalam Sinode GMIBM berupaya untuk melaksanakan beberapa program. Program-program itu bertujuan membentuk dan mengembangkan pengetahuan warga gereja dan masyarakat untuk menjaga, memelihara, dan melestarikan lingkungan hidup (Badan Pekerja Sinode GMIBM, 2016: 49). Salah satu metode yang digunakan dalam melaksanakan program ini adalah dengan cara menyampaikan pengajaran melalui khotbah dan katekisasi tentang etika dan teologi Kristen yang mengarusutamakan pentingnya keterlibatan gereja secara kelembagaan maupun individu dalam mencegah kerusakan alam akibat dari ulah manusia yang mengeksploitasi alam. Hal ini demi kepentingan ekonomi tanpa memerhatikan dampaknya yang bisa mengancam kelangsungan hidup seluruh makhluk hidup ciptaan Allah.

Selain mengonstruksi pengetahuan dan melakukan sosialisasi terkait dengan etika dan teologi ekologi Kristen, GMIBM juga melakukan beberapa program pelatihan yang bertujuan membentuk dan mengembangkan kemampuan/keahlian warga gereja dalam memanfaatkan sampah untuk keperluan kesuburan lahan pertanian dan atau kerajinan tangan yang dapat dikomersialkan oleh warga gereja. Salah satu program GMIBM yang bersentuhan langsung dengan kawasan TNBNW adalah penanaman pohon di beberapa lokasi yang termasuk dalam wilayah kerja Resort Dumoga Barat. Kegiatan ini diprakarsai oleh Komisi Pelayanan Kategorial (KOMPELKA) Kaum Bapak GMIBM. 


\section{Pembahasan}

Masyarakat yang berada di kawasan TNBNW, sumber daya alam yang terkandung di kawasan konservasi darat ini sangat berpotensi untuk kesejahteraan ekonomi mereka. Namun dalam pemanfaatannya masyarakat tidak boleh secara serampangan menggunakannya, tetapi harus menyesuaikan dengan pelembagaan pelestarian ekosistem hutan yang ada di kawasan TNBNW.

Merujuk pada pemikiran Peter L. Berger, kenyataan yang digunakan dalam karya tulis ini dimaknai sebagai lebenswelt (terjemahan bahasa Inggris life world, dalam bahasa Indonesia diterjemahkan menjadi dunia kehidupan). Kenyataan ini yang menjadi objek kajian dari sosiologi untuk ditafsirkan dan dipahami dengan menggunakan pendekatan dan metode tertentu (Frans M. Parera dalam Peter L. Berger, 1990: xiv).

Kenyataan hidup sehari-hari terbentuk secara dialektik yang melalui tiga momentum, tahapan atau langkah, yakni eksternalisasi, objektifikasi dan internalisasi (Berger, 1991: 4). Demikian juga dengan TNBNW sebagai suatu kenyataan kehidupan sehari-hari bagi masyarakat di Kecamatan Dumoga Barat, khususnya bagi warga GMIBM di wilayah tersebut. Bagi warga GMIBM yang bermukim di sekitar TNBNW, sekalipun TNBNW bukan suatu kenyataan (lebenswelt) yang dibentuk oleh warga GMIBM, tetapi TNBNW menunjukkan dirinya sebagai suatu kenyataan yang objektif bagi warga GMIBM. Dikatakan objektif karena kenyataan itu dihadapi oleh warga sebagai suatu fakta yang eksternal dan memaksa. Objektifitas TNBNW ini tampak dari dilembagakannya tindakan masyarakat dalam memperlakukan sumber daya alam yang terkandung di TNBNW; ini bersifat eksternal dan memaksa. Bahkan, di masa orde baru, kontrol terhadap aktivitas masyarakat di kawasan TNBNW pernah dilakukan dengan menggunakan cara militeristik.

Sumber legitimasi TNBNW adalah regulasi yang telah ditetapkan oleh pemerintah. Regulasi yang dijadikan sebagai rujukan utama dalam menata pengelolaan TNBNW di satu sisi merupakan manifestasi dari paradigma konservasi sumber daya alam yang dikembangkan oleh lembaga-lembaga konservasi international. Pada sisi yang lain merupakan perwujudan dari kepentingan pemerintah dalam penguasaan hutan sebagai milik negara. Padahal, bila mengacu pada pemikiran Peter L. Berger, agama merupakan salah satu sumber legitimasi yang adi luhung. Akan tetapi, yang menjadi soal adalah dalam konstruksi ketatanegaraan modern, agama semakin tersingkirkan dan inilah yang disebut dengan sekularisasi. Walaupun demikian, bukan berarti bahwa dalam suatu negara modern dapat dipastikan sekularisasi juga 
Volume : 6
Nomor : 4
Bulan : November
Tahun : 2020
E-ISSH: 2656-940X

P-ISSH: 2442-367K

URL: jurnal.ideaspublishing.co.id

sudah berlangsung secara merata dalam kesadaran warga negaranya. Jadi, terbuka kemungkinan ada ketidaksamaan antara proses sekularisasi sosial dan struktural dengan proses sekularisasi pada tataran budaya dan individu (subjektif) (Berger, 1991: 127-128). Fakta inilah yang terkadang menjadi salah satu sumber penyebab masalah dalam kebijakankebijakan publik yang menjadi wewenang dari pemerintahan di negara-negara yang mengadopsi sistem ketatanegaraan demokratis dan modern.

Indonesia, sekalipun mengadopsi sistem politik dan pemerintahan/birokrasi yang demokratis dan modern, bukanlah bangsa dan negara yang sekular. Namun, kehadiran pergerakan nasionalisme di Indonesia tidak berbarengan dengan memudarnya pengaruh agama dalam masyarakat Indonesia. Bahkan sebaliknya, agama menjadi salah satu falsafah hidup yang sangat berpengaruh dalam proses awal pembentukan negara dan bangsa Indonesia (Latif, 2011: 55-56). Bahkan, hingga era reformasi ini, realitas sosial dan politik Indonesia sangat dipengaruhi oleh agama.

Persoalannya kehadiran agama di Indonesia terkadang memudar dalam ruang publik dan lembaga-lembaga politik dan sosial, khususnya yang bersentuhan dengan isu-isu pelestarian alam dan keadilan ekologi. Bahkan, di kalangan umat Kristen berkembang pemikiran bahwa isu-isu ekologi bukan menjadi tanggung jawab gereja, baik itu secara individu maupun kelembagaan, dan menyerahkan penanganan masalah tersebut kepada negara. Tentu tidak dapat juga dinafikan bahwa gereja sudah mengupayakan penanganan masalah ini melalui edukasi/literasi dan praktik hidup yang ramah lingkungan, tetapi advokasi lingkungan tidak hanya sebatas pada lingkup pengetahuan dan pembentukan perilaku hidup yang ramah lingkungan.

Mengutip pendapat John Simanjuntak, "Advokasi lingkungan adalah upaya bersama untuk memperjuangkan keadilan ekologis secara teratur dan kontinu antara lain dalam ruang pengelolaan negara”. Dengan demikian, gereja yang berniat untuk mengambil perannya dalam advokasi lingkungan dituntut juga untuk melakukan litigasi terhadap pemanfaatan sumber daya alam yang mengancam kelestarian ekosistem di satu wilayah. Dalam hal inilah, kehadiran agama dirasakan masih sangat lemah bahkan cenderung tidak ada sama sekali, hal mana juga berlangsung di Gereja Masehi Injili di Bolaang Mangondow. Tidak adanya upaya GMIBM memperjuangkan keadilan ekologi secara struktural yakni dalam ruang pengelolaan negara dengan alasan bahwa itu bukan menjadi urusan gereja menunjukkan masih belum berkembangnya perspektif teologi pembebasan di GMIBM. 
Hasil konstruksi pengetahuan tentang betapa pentingnya TNBNW bagi masyarakat di Kecamatan Dumoga Barat Kabupaten Bolaang Mongondow Provinsi Sulawesi Utara, dengan semakin tingginya tingkat kepedulian mereka untuk tetap menjaga kelestarian TNBNW dengan berbagai kegiatan pelestarian. Hal ini tidak terlepas dari peran GMIBM sebagai lembaga sosial keagamaan yang menganjurkan secara langsung kepada umat gerejanya agar tetap memelihara dan menjaga lingkungan TNBNW sebagai bagian dari siklus kehidupan umat manusia.

\section{Simpulan}

GMIBM telah terlibat dalam upaya memelihara kelestarian ekosistem TNBNW melalui beberapa program yang terorganisasi/terlembagakan dan terencana dengan baik. Keterlibatan itu berlangsung dari aras sinodal hingga wilayah dan jemaat. Keterlibatan itu diwujudkan dalam bentuk keputusan dalam persidangan yang kemudian direalisasikan dalam beberapa program kegiatan, di antaranya adalah penghijauan, pelatihan dan pengajaran. GMIBM diharapkan dapat memberikan peran yang lebih signifikan dalam proses legitimasi dan sosialisasi untuk mendukung upaya pelestarian ekosistem TNBNW. Namun, peran tersebut belum dapat terealisasi secara maksimal. Beberapa pokok persoalan lemahnya peran GMIBM ini disebabkan oleh begitu dominannya negara dalam tata kelola pelestarian TNBNW. Bahkan, dapat dikatakan bahwa TNBNW bukanlah merupakan suatu dunia kehidupan (lebenswelt) yang melibatkan masyarakat sipil dalam proses pembentukannya. Ini juga menambah sederetan fakta yang menunjukkan tindakan-tindakan eksklusi dalam tata kelola wilayah konservasi di Indonesia.

Pada tahapan objektifikasi, ditemukan beberapa hambatan untuk lebih meningkatan peran GMBIM dalam melestarikan ekosistem TNBNW. Masih belum berkembangnya dengan baik perspektif teologi Kristen yang dapat mendorong upaya advokasi dalam memperjuangkan keadilan ekologi secara struktural dalam ruang pengelolaan negara merupakan salah satu penghambat. Sehingganya, GMIBM belum berperan lebih besar dalam melegitimasi kebijakan-kebijakan bagi litigasi atas pemanfaatan yang sumber daya alam di kawasan TNBNW yang mengabaikan kelestarian ekosistem di kawasan TNBNW. 
Volume : 6
Nomor : 4
Bulan : November
Tahun : 2020
E-ISSH: 2656-940X

P-ISSH: 2442-367K

URL: jurnal.ideaspublishing.co.id

\section{Daftar Pustaka}

Berger, Peter L. (1991). Langit Suci: Agama Sebagai Realitas Sosial. Jakarta: LP3ES.

Berger, Peter L., dan Thomas Luckmann. (1990). Tafsir Sosial atas Kenyataan: Sebuah Risalah tentang Sosiologi Pengetahuan. Jakarta: LP3ES.

Creswell, John W. (2012). Research Design: Pendekatan Kualitatif, Kuantitatif, dan Mixed. Yogyakarta: Pustaka Pelajar.

Drummond, Celia Deane. (2016). Teologi dan Ekologi. Jakarta: BPK Gunung Mulia.

Halid, Amir. (2012). "Model Kelembagaan Pemanfaatan Sumber daya Tambang dan Kaitannya terhadap Pembangunan Wilayah di Kabupaten Bone Bolango Provinsi Gorontalo (Studi Kasus Arah Pengelolaan Kebijakan Ekonomi di Sektor Pertambangan Pasca Perubahan Status Sebagian Kawasan Taman Nasional TNBNW melalui RTRWP Gorontalo)". Disertasi. Sekolah Pasca Sarjana IPB Bogor.

Hamidun, Marini Susanti. (2012). "Zonasi Pengelolaan Taman Nasional dengan Pendekatan Ekowisata (Kasus Calon Taman Nasional Nantu Boliohuto di Provinsi Gorontalo". Disertasi. Sekolah Pasca Sarjana IPB Bogor.

Hardiman, F. Budi. (2003). Melampaui Positivisme dan Modernitas: Diskursus Filosofis tentang Metode Ilmiah dan Problem Modernitas. Yogyakarta: Kanisius.

Johnson, Doyle Paul. (1988). Teori Sosiologi Klasik dan Modern, Jilid I. Jakarta: PT Gramedia.

Miles, Matthew B, dan A. Michael Huberman. (2014). Analisis Data Kualitatif: Buku Sumber Tentang Metode - Metode baru. Jakarta: Penerbit Universitas Indonesia.

Noor, Irfan. Realitas Agama dan Problem Studi Ilmiah-Empiris (Kajian Filsafat Ilmu atas Pemikiran Peter L. Berger), diakses 15 Oktober 2015, http://id.scribd.com/doc/7980498/Agama-Dan-Filsafat-Ilmu-Irfan-Noor.

Pals, Daniel L. (2012). Seven Theories of Religion. Yogyakarta: IRCISOD.

Sanks, T. Howland. A Tradition In Process: The Changing Face Of Theology, American Magazine: The National Catholic Review, vol. 2015, 24 Oktober 2011, diakses pada tanggal 15 Oktober 2015. http://americanmagazine.org/ sites/default/files/issues/cf/ pdfs/791_1.pdf.

Syah, Siti Fauziah. (2018). "Peran GMIBM dalam Pelestarian Lingkungan di Taman Nasional Bogani Nani Wartabone (TNBNW) di Kecamatan Dumoga Barat”. Skripsi. Program Studi S1 Sosiologi, Fakultas Ilmu Sosial, Universitas Negeri Gorontalo.

Turner, Bryan S. (2012). Relasi Agama dan Teori Sosial Kontemporer. Yogyakarta: IRCISOD.

Veeger, K. J. (1993). Realitas Sosial: Refleksi Filsafat Sosial Atas Hubungan Individu Masyarakat Dalam Cakrawala Sejarah Sosiologi. Jakarta: Gramedia Pustaka Utama. 
ZE E-ISSH: 2656-940X (D) P-ISSH: 2442-367K

URL: jurnal.ideaspublishing.co.id
Volume : 6

Nomor : 4

Bulan : November

Tahun : 2020 